Saša Stamenković ${ }^{1}$

Siemens

Milan Stamatović ${ }^{2}$

Union Nikola Tesla University,
SCIENTIFIC REVIEW ARTICLE doi:10.5937/ekonomika1803103S

Received: January, 29, 2018 Accepted: April, 20, 2018

\title{
IDENTIFYING AND INTERPERTING MARKET INFORMATION WHEN MAKING BUSINESS DECISION ${ }^{3}$
}

\begin{abstract}
This paper makes reference to the identification, origin, and method of creation of market information which, in its short life, represents market signals of different values and the manner in which it is perceived by the companies' managements. The impacts of globalisation, the development of transport, and IT technologies have given a multidimensional line to the market signals and their complexity. The paper presents some of the challenges arising from the growing amounts of information available and exhausting the managements when defining the direction of future development of a company. Actually, the paper aims at making closer the understanding of the difference between data and information, from today's point of view, the interpretation of market signals and their further use in making business decisions, looking through the prism of the constant increase in the quantity of information available in the light of globalisation and IT technologies, as well as possible challenges posed by the increasing amount of information. Finally, the paper presents a part of research that was used for the preparation of a doctoral thesis on information and its role in business decision-making.
\end{abstract}

Key words: globalisation, information, environment, market signals, information overload.

JEL classification: D 80, D 83, G14

\section{ПРЕПОЗНАВАЊА И ТУМАЧЕЊЕ ИНФОРМАЦИЈА СА ТРЖИШТА ПРИЛИКОМ ДОНОШЕЫА ПОСЛОВНИХ ОДЛУКА}

\begin{abstract}
Апстракт
У овом раду је направљен осврт на препознавање, порекло и начин настајања информаџија на тржишту које у свом кратком животу представљају тржишне сигнале различите вредности и како их доживљавају руководства компанија. Утицај глобализащије, развоја транспорта и ИТ техно-

\footnotetext{
${ }^{1}$ sasa.d.stamenkovic@siemens.com

${ }^{2}$ stamatovicm@sbb.rs

${ }^{3}$ The paper used the part of the research from the doctoral dissertation "Management of the factors of the performance of strategic changes in the organization"
} 
логија су донеле мултидимензионалну ирту тржишним сигналима и њихову сложеност. Приказани су неки од изазова који настају растом количине доступних информација и исирпљују руководства приликом дефинисања праваца будућег кретања компаније. Управо, рад има за ичиь да приближи разумевање разлике између податка и информације, са данашьег аспекта, тумачење тржсиних сигнала и њихову даљу употребу у доношењу пословних одлука, посматрајући кроз призму сталног пораста количине доступних информација а светлу глобализачије и ИТ технологија, као и могуће изазове које све већа количина информачија ствара. На крају рада је дат део истраживања који је коришћен за израду докторске тезе о информацијама и юиховој улози на дономење пословних одлука.

Кључне речи: глобализација, информачија, окружење, тржишни сигнали, преоптерећење информацијама

\section{Quantity of available information and today's growth of the quantity of information}

The quantity of information is growing at such a speed that even the use of the best resources of information technologies for analysis does not result in a possibility of consideration and forecasting of market trends.

Whether our search for information is of a passive nature or has an aim, it is certain that in the world's ocean of information it is very difficult to find the right information. Obviously, the main reason is the huge amount of information that is available to us at any time in this information era. The fundamental issue is the origin of information and its availability. By 2007, television and radio systems had transmitted approximately 1.8 zettabytes of information (a zettabyte is one thousand trillion bytes), or every person in the United States tweeting 3 tweets per minute for 26,976 years nonstop. According to a new study by IDC, a market research company, the amount of information in the world doubles every two years, putting to the test companies engaged in organising its flow. The force of this flow is compared to a tsunami in the information market. Just for comparison, according to the estimate of scientists, this quantity represents only one percent of the information contained in all DNA molecules of a human. ${ }^{4}$

\section{Globalisation and media, their connection with the growth of the quantity of information}

"Positioning - once the heart of the strategy - is rejected as too static for today's dynamic markets and changing technologies. According to the new dogma, rivals can quickly copy any market position, and competitive advantage is, at best, temporary." (Porter, 1996, p. 2)

In the last 20 years the whole world has been living in capitalism (though at

${ }^{4}$ Sources: http://www.emc.com/about/news/press/2011/20110628-01.htm 
different stages) and today when information technology (IT) has reached the highest point of the former's development, both these facts are excellent preconditions for globalisation to have its highest swing, irrespective of the global crisis.

Globalisation, the main carrier of transformation in history, generates a multidimensional impact on technology, economy, society, culture, politics, and geopolitics. The driving engines of globalisation are trade, investment, development of all new technologies, and especially information technology. At the same time, it is a process which, through the influence and connection between people, companies, and governments of different countries, is the driver of trade and investment and uses the overall process of technology progress towards economic development and prosperity. Development of IT technologies and transport provides freedom of movement of people and capital without restrictions. Globalisation as a phenomenon has a dual role; on the one hand it uses multifold media tools and generates a need, the same or similar for everybody, and then sells a product or service. This simply means that today, globalisation generates a need and satisfies this need.

Thomas L. Friedman in the book The Lexus and the Olive Tree said that today's globalisation is "Farther, faster, cheaper, and deeper."

In short, globalisation is a process that goes beyond the borders of national states and operates economically, culturally, and politically on the environment, leading to knowledge transfer, increasing the exchange of capital, services, products, energy, and alike (Stamatović, Vukajlović, \& Cvetanović, 2012).

Media and the Internet are the holders of information, by their continuous development in information technology from teletype, telephone, fax, messaging, mobile phones, video calls through the Internet, which nowadays represents the primary means of knowledge and the holder of information of the developed part of humanity. The Internet very skilfully uses curiosity, a basic human feature that generates the need for new information. Media and the Internet in the digital and information age do not have any limitation in the amount of available information, which easily leads to its overload. All companies operating in the global or a local market receive and send certain signals but, at a time of huge quantities of available information, it is difficult to identify which information is useful and which is not.

Through the advancement of technologies, especially in transport and IT, the world is becoming an "electronic global village" as described by the Canadian Professor Marshall McLuhan, in his books The Gutenberg Galaxy: The Making of Typographic Man (1962) and Understanding Media (1964), i.e. a "stage of social development" that is defined as an information society. We can surely say that we are living the future and that the holders of information allow the media to spread and the world to 'shrink'.

The excessive amount of information which the user of the digital (new) media is exposed to implies the growing numbers of e-mails, voice messages, flash news, and electronic images that we are overwhelmed with every day, which results in stress, confusion, impaired ability to control our own lives. Free time is shortened, the global village is increasing, and loneliness grows (Stamenković, 2011). Information overload does not only mean stress in one's life but also impossibility of its processing in a short period of time, which can contribute to the omission of essential, and placing emphasis on irrelevant information.

\section{Dependence on information}


"Never mind what industry you're in, how big and well known your company may be, or how clever your strategy is. If you can't make the right decisions quickly and effectively, and execute those decisions consistently, your business will lose ground" (Rogers, \& Blenko, 2006, p. 2). Having in mind that access to information today is not a privilege but a standard, it is difficult to make a big differentiation among organisations.

Information as knowledge has always been used for the production of goods and services; organisations benefited from it to become more efficient and effective by regulating the organisational processes, and in addition, processes of optimisation of the production were carried out, and it was used for the implementation of management processes, etc. However, information today is the key, the basis, the fundament through which the objective and the key source of production is achieved. Former primary factors of production such as land, labour, and capital are not sufficient nowadays to achieve a competitive advantage in the market unless the available information and knowledge is used first. Looking at the environment as a source of resources, this approach considers the environment a source of rare and necessary resources which many competing organisations are aiming at. As a result, new drivers have continuous changes, reduction of the need for physical assets, unnecessity of space and time constraints and risk exposures, as well as statelessness in the familiar meaning of the world. Moment, when the companies diagnosed source of a problem, present starting point to design a solution. Managers can use architecture concept introduced the goal and improve people's decisions by carefully structuring how information and options are presented to them (Beshears,\& Gino 2015).

Organisations exposed to hostile environments are exposed to greater uncertainty and the idea of the management is to acquire and gain control over all critical resources.

Today we live under constant new requirements caused by changing consumer taste, changing technology, the constant pressure of competitors, merging of companies and capital.

On the one hand, development of information technology on the global level brings rapid exchange of information and all the conveniences and comfort that we are increasingly used to; however, the higher the level of used technologies is, the larger our dependence on them. Our dependence rises to the surface at a time when there is a failure or unavailability of access to it. Because even in times of high technologies it is impossible to prevent the interruption of power supply and similar events.

Negative dependences, for example, are the global spread of computer viruses, a desire to express dissatisfaction by subverting or changing some sites that, whether we like it or not, have implications on our daily life. We are witnessing that the fall of the IT systems of banks has a consequence that we are unable to withdraw money or perform simple payments. We are not able to watch our favourite programme or review the electronic version of the daily newspaper or read our e-mail or electronic edition of a magazine.

Since information is, today, an invaluable resource, it has certainly become a target of terrorist, competitive, biological attacks, so it is mandatory that the makers of strategic decisions in companies are aware that due to the possession or use of information, their capital, capacities, and employees are exposed to constant risk.

Mankind has learned to collect, download, sort, filter, and adjust information 
(Glevick, 2012). Media literacy is not merely the use of media, familiarisation with them. Most media illiterate people yield themselves to the media and allow the media to program them, creating their habits in the manner of the use of the media. In this way they "program the way of their looking at the world, influencing the expectations of interpersonal relationships, personal attractiveness, success, fame, health, events that are worthy of media attention, problems and solutions to them" (Potter, 2011). Information is expensive and subject to changes, it has its positive and negative dimension (Cunningham, 2001).

Information is knowledge which decisions are based on (Milisavljević, 2001). The term information usually has a general meaning, but frequent use of this term even in normal speech, and in techniques, and generally in science suggests that it is, although pretty inaccurate, still acceptable in communication. This term is used in a similar way as the term announcement, but with one important difference. The term information is related to particular valuation of specific technical nature, not from the areas of philosophy and knowledge. Thus information is seen as a quantified and measurable announcement. On the other hand, the term announcement often overlaps with the term data, i.e. these two terms are not mutually clearly delimited, but it is usually considered that data is the physical realisation of announcement. Data is the carrier of information and is used for technical shaping of the information so that it can be stored and transferred. So, from the technical aspect, information is interpreted data on the phenomenon that the data shows. The task of the information system today is data collection and processing, exchange and transport of information over some spatial distances, as well as analysis of information required at the respective hierarchical levels of the organisational structure.

The information that recipients receive depends on the recipients themselves, their education, processing capabilities, and alike. The subjective value of the information (Wang, \& Strong, 1996) means:

- Value inherent (intrinsic) to the user: accuracy, objectivity, confidentiality, reputation of the source;

- Contextual value: relevance, added value, timeliness;

- Representational value: ease of understanding, interpretability, concise representation, consistent representation;

- Access value: access and access security.

\section{Ways of obtaining information and obstacles in the way of getting the right information in the world market}

It is often said in modern business that information is "the most expensive resource". Information that is correct and provided in the right time can lead to business progress and success. However, a greater importance of information is in its combating business risk and preventing adverse situations. The basic forms of business information include: news, market research, financial and credit information, company and executive data, industrial and economic analysis, IT research. Basic business information can be divided into the following categories (Moss, 2004):

- Basic resources such as guides, bibliographies, dictionaries, encyclopaedias, 
manuals, yearbooks, internet sources;

- Archives;

- Newspapers;

- Government information and services;

- Statistics;

- Electronic business information.

The value of the information in terms of decision-making can be viewed through certain characteristics such as time frame, objectivity, accuracy, adequacy, availability, completeness, conciseness, and affordability. Use of information in business is of great importance, especially in times of crisis or planning of changes. Adequate information is of paramount importance before starting work, and after finishing work its importance is reflected in the measurement of what has been achieved and planning corrective actions. Using the information can be viewed from several aspects: monitoring, help in decisionmaking, measuring of the execution and identifying new business opportunities.

The most important element of business planning is to ensure continuous access to information and data that will be guidelines to the crisis management team at the moment when a crisis is on the horizon. If a crisis has already occurred, you can take advantage of certain information that can help organisations to recover quickly and more efficiently, such as going concern documents, access, availability, and security and testing of the processes.

It is normal nowadays that almost all media are possessed by a very low percentage of media conglomerates. With that in mind, there may be situations in which media are possessed by companies that have replaced the freedom of speech by the formula of maximising their profit. The race for profit, not for truth is the current trend of media. Only the increase of the advertising trend rather than journalism is felt.

The strong social impact of the media is recognisable, and therefore it is necessary to legally regulate them differently from other commodities. Free market exists for a large number of other services and goods, which is not the case with the media on the pretext that it is harmful to society, such as: companies are no longer foreign, they are international now. The large conglomerates control the world's media: books, magazines, newspapers, recording and releasing records, TV production, TV stations and cable channels, satellite TV systems, film production, cinemas.

The "global village" is managed by centralised media conglomerates with the greatest size and power in the history of the mankind. It is impossible to control those factories of information which many people and decisions arising therefrom depend on. Today's media empires include: databases, service news, newspapers, magazines, TV and radio stations, publishing, and so on. Digitalisation of the news and capitalism are the initiators of the mass distribution of information and one of the drivers of globalisation. Production of news is obviously a highly profitable industry and it is the heart of modern capitalism.

Today, there are simply no obstacles to unilateral influence. People are simply living the news today, which breaks the established ideas of space and time. In his book Public Opinion Walter Lippmann made the difference between the picture of the environment (the world that is really around us) and the pseudo environment (our private perception of that world around us). With this way of life in the "global village" we should not 
live under the illusion that we all have the same chance to change the way of life using the media. Monopolistic behaviour aims at one more aspect, commercialisation, for the reason that the basic content of the most of the media is the news.

We bear witness that the traditional role of the media is to control the media processes and work on shaping the democratic thinking. The only product of media is shaping the behaviour and opinions of people. Besides, they have a great impact on the culture.

\section{Obstacles in identifying market signals and types of market signals}

Market signals are information emitted by companies, and represent an indirect way of communicating in the market. Most signals carry information that can help in the analysis of competitors and strategy formulation. The market does not recognise another way of communication except the indirect way of communication using market signals. Market can allocate resources efficiently only under appropriate conditions. In the case of a lot of information and competition, people still can make rational choices.(Pfiffer, 2009)

Most signals carry enough information that can help concerning analysis of competitors and definition of strategies. Any activity by competitors in the market, which provides direct or indirect indication of the intentions, motives, goals, or an internal situation, represents a market signal. There are a myriad of signals in the market, some signals are fake, some are bluffs, some warnings, and some signals represent a genuine response to a current situation. Identifying and correctly reading the market signals is the most significant factor in the formulation of strategy. A prerequisite for correct identification of signals is a condition that based on competitor analysis, one identifies the following moves of the competition: future goals, and assumptions about the market and about themselves, current strategies and opportunities.

Reading of the market signals is the second most important information about competitors immediately after the information obtained after comparing the known facts about the competition and their behaviour. A leadership has a very important role in organization with behaviour, values, attitudes, characteristics, skills and abilities present the greatly influences on the decision making (Micić, 2015).

Market signals have two fundamentally different functions; they can be true indications of specific motives, intentions, or goals, or they can be bluffs. Bluffs as signals are intended to deceive other companies in taking or not taking actions that may give an advantage to the company that sends signals. The assessment that can make a difference between the bluff and right signals can be a significant advantage when defining the competitive strategy. "We found that decision effectiveness and financial results correlated at a $95 \%$ confidence level or higher for every country, industry, and company size in our sample." (Blenko, Mankins, \& Rogers, 2010, p. 3).

For most executives, the decision-making process has more layers. "First, they need to quickly grasp the relevant facts (getting them from people who know more about the details than they do). Second, they need to fi gure out if the people making the 
recommendation are intentionally clouding the facts in some way. And fi nally, they need to apply their own experience, knowledge, and reasoning to decide whether the recommendation is right "( Kahneman, \& Lovallo, \& Sibony 2011, p. 53.).

Managers are more committed to their firms ongoing strategies so their ability to recognize unrelated data and other environmental stimuli, are significantly reduced, and so they will "actively ignore" data that are inconsistent with those strategies ( Jovanović, 2015).

In his book Competitive Strategy, Michael E. Porter defined the types of signals that are mentioned with their explanations. Market signals have different forms depending on the behaviour of competitors. When we talk about different forms of signals, it is necessary to interpret the identified signals in whether they are used as bluffs and how bluffs and true signals can be differentiated.

Prior announcements of moves - The form, character, and time frame of the prior announcement can be a potential signal. Prior announcements of the competitors can be a way of formal announcements in order to take or not to take an action. Prior announcements of the moves, whether they are given or not, doesn't have to have behind any action in practice.

Prior announcements of moves can send multiple signals to the market as, for example, they may be attempts to take measures that reduce the impact of other competitors.

For example, if a company announces expansion of its production capacity so that it covers the planned industrial growth in the production branch, this information can discourage other competitors to expand their production capacities. In the example of the IT industry, there are often announcements of the release of new products or gadgets by which the public is polarised and waits for the release, and a large number of orders, which normally determines the direction in this segment of products. Prior announcement of moves can also be a threat to the actions to be taken in the event the competitors continue with their moves. The third announcements can be related to the test for competitors' feelings and obtaining advantage regardless of whether the announcement should be sent by any action or not. The fourth role of the previous announcement can be communicating of satisfaction or dissatisfaction with the competitive development of the industry. The fifth role can have a joint function with the announcement to announce steps aimed at minimising provocations from communicating satisfaction or dissatisfaction.

The sixth role can be related to avoiding expensive simultaneous shifts in the market of expansion of production capacities, which can lead to too much manufacturing capacity in that branch of the industry.

Communication with the financial community can be one of the ways of prior announcements. For example, publication of the results in the last quarter, the number of produced units, or gathering internal support for further processes.

Announcements of results or actions after the fact - Companies often announce additional factories, sales figures, and other results or actions after their occurrence. Such announcements often carry signals to a degree that is hard to obtain and they are a surprise for the public. So, it can happen that information that is announced in this way can be a turn from the right direction and throwing dust in the eyes. Many have not reviewed such figures relating to market share and they are not subject to audit or not 
fully in line with the procedures of control. Often erroneous data are announced with the idea that such data demonstrates a company's commitment to achieve a certain result in the market.

Public discussions of the industry by competitors - It is not unusual for competitors to comment jointly the conditions in the industry, the predictions in sales and price required, future capacities, significant external changes as well as an increase in the price of materials and alike. Such comments can be guided with the idea that the assumptions that exist in the company regarding certain information are to be checked before their building into the new strategy.

These can be conscious and unconscious attempts by companies to equalise the starting positions for all companies operating in the same industry and to minimise the possibility of error and wrong motives by introducing a new strategy.

Such discussions can include requests to regulate prices in the market, solve the surplus or deficit of production capacities, commitment to the work with certain customers and similar. Normally these announcements can often be comments on the state in the industry with a desire to improve their pricing policy or production capacity in relation to the competitors.

Competitors discussions and explanations of their / own moves - It often happens that competitors discuss their moves publicly or at fora with a wish to include other companies as well. The inclusion of competitors in explaining their own moves intentionally or unintentionally can have at least three reasons:

The first reason is that other companies see the logic of the move and follow it or communicate it so that the move is not perceived as a bluff.

The second reason is an explanation or discussion of the move as a preventive move. For example, to discuss release of a new product or a new market as a very large and expensive effort of the company, this would deter other companies to try something similar.

The last reason is to communicate commitment and persistence on the undertaken journey course.

Competitors' tactics relative to what they could have done - Tactics is often a relationship between what the competitors tried to do and what they advertised, taking into account the price and extent of advertising that are actually selected, the size and capacity of the chosen strategy. Such moves have all the important signals about the motives.

The manner in which strategic change is initially implemented - The latest product of the competitors can be initially introduced in the market or sold to competitors. This is just an example of a possible application of a certain strategy and can help between the desires of the competitors to strike a decisive blow in their desire to make a move in the best interest of the industry as a whole. If such interests are in the game, then it is a bluff.

Divergence from past goals - The desire to move away from historically set products or goals by their replacement with a much weaker product can send a very strong signal or suspicion.

Such a decision could lead to a period of continuous observation of other signals 
and the competitors' analysis.

Divergence from industry precedent - Divergence from industrial norms represents an aggressive signal.

The Cross - Parry - If an organisation enters a new market on its own initiative and the competitors from that market enter into their market, this move is called crossparry. Such moves represent an indirect way to defend the market from competitors. Such moves represent measures and countermeasures to protect own markets and can be interpreted as signals of discomfort and later grow into signals of fear. Such intrusions in smaller markets can be interpreted as warning signals. This can be measures for disciplining of the competitors in an industry where major difference between the controlled parts of the market exists.

The fighting brand - A form of the cross-parry is also the fighting brand. The fighting brand is a warning or an obstacle or an impact force to absorb the greatest burden of competitors' attacks. They are often presented as a small encouragement or support before any serious attack. The fighting brand can also be used as an offensive weapon as part of a large campaign.

Private antitrust lawsuit - Using documents from the private antitrust lawsuits can be interpreted as a signal of discomfort or harassment or of tactics with delayed effect. Private lawsuits can be interpreted as a cross-parry. Lawsuits of large companies against small companies very often result in the inferior companies having to pay high court costs in a long time. This may be a signal to small companies to reduce their presence in the market, and thus the suits are used as a signal of pressure on smaller firms.

The use of history in identifying signals - Studying the historical links between communications of companies can identify different forms of potential signals and their accompanying expressions, which can have a possibility of a better and more accurate reading of the market signals. Secure monitoring of market signals and different situations can result in better prediction of certain situations which gives the company opportunities for quicker and more accurate response.

Constant attention to the market signals can be an obstacle. An excessive preoccupation of the management with the market signals can result in playing down business development and creation of a strong position in the market. Knowing the position of the competitors and understanding the market signals can improve the quality of understanding of the market while their ignoring can lead to ignoring the competitors themselves, which is not a task.

Organisations cease to believe the market signals after the entry of new players in the market, by changing the conditions, the recent war operations, or other causes of instability and the increase of the capacity by increasing the process. Signals that are credible allow promotion, regular rise, allowing the company to warn others to planned moves, to plan the expected start and completion of capacity expansion.

\section{Disadvantages of continuous information gathering}


Information overload is the term used for the first time in 1964 by Bertam Gross in the book Managing of Organisations. It was used and popularised by Alvin Toffler in the book Future Shock in 1970.

Increasing the number of websites constitutes an endless source of information and creates dependency on such a method of obtaining information. With this in mind, you come to a new method of obtaining information and writing texts. Lawrence Lessig defines and describes the "read-write" internet culture.

Normally, the issue of the root of information on the Internet and its verifiability and benevolence arises due to its very easy modification. The problem of the omniscient Internet is that there is no one you can discuss the obtained information with, which can lead to misunderstanding or misinterpretation and misuse.

Basics of the information overload are:

1. Enormous growth of new sources of information;

2. The ease of duplication and transmission of data;

3. Increase of data transfer channels (phone, e-mail, instant messaging);

4. Large amounts of historical information;

5. Contradictions and inaccuracies in available information;

6. Lack of methods for comparison of accuracy and processing of different types of information;

7. Pieces of information are unrelated or do not have the overall structure in order to be connectable;

8. Poor signal strength relative to noise.

The following text will present a part of research for the doctoral dissertation oriented to information, its quality, and symbiosis of the quality of information and making business decisions.

The study has been designed as transversal (cross-sectional study), and has been organised for the purpose of description of phenomena (the willingness of companies to respond to change, change management, and information and information quality). The study should provide an analysis of the relation between variables in order to determine their conditionality and connection.

The first level of the research was conducted as a case study in an organisation that operates in the energy sector on the territory of Belgrade, and is a regional company in a global corporation. With occasional small fluctuations, the number of employees was 130. We handed out 124 questionnaires, out of which 102 were validly completed and returned and were taken into account when processing the data.

The second level of research was conducted as a survey on a random sample of the population in Belgrade, Subotica and Novi Sad. In total 400 questionnaires were distributed, and out of them 315 were validly completed and returned and were taken into account when processing the data. The questionnaires were collected by their delivery in person.

The questionnaire consisted of 11 closed questions, of which 5 (gender, age, education, field of work, position in the company) were the independent variables, and 6 were the dependent variables. For 7 questions related to the frequency of viewing certain media, the respondents were supposed to cross an answer, while for 7 questions they 
were supposed to assess the quality of specific information.

One hypothesis that has been placed and discussed in the paper: Is there a difference (interaction) in the assessment of the quality and the relation according to the information provided by respondents employed in a company operating in the energy sector and those that are included in a random sample, who have different levels of education and are of different age.

Characteristics of the sample of respondents working in the energy sector (RWES):

Table 1. shows specifics of the RWES sample

\begin{tabular}{|c|c|}
\hline \multicolumn{2}{|c|}{ Gender } \\
\hline Male & Female \\
\hline 54 & 48 \\
\hline
\end{tabular}

\begin{tabular}{|c|c|c|c|}
\hline \multicolumn{4}{|c|}{ Age } \\
\hline Up to 25 & 25 to 35 & 36 to 45 & Over 45 \\
\hline 7 & 42 & 33 & 20 \\
\hline
\end{tabular}

\begin{tabular}{|c|c|c|}
\hline \multicolumn{2}{|c|}{ Education } \\
\hline Elementary and secondary & College & Faculty \\
\hline 11 & 11 & 80 \\
\hline
\end{tabular}

\begin{tabular}{|c|c|c|c|c|}
\hline \multicolumn{5}{|c|}{ Field of work } \\
\hline Sale & Management & Production & Marketing & Finance \\
\hline 43 & 14 & 19 & 2 & 24 \\
\hline
\end{tabular}

\begin{tabular}{|c|c|c|c|}
\hline \multicolumn{4}{|c|}{ Position } \\
\hline Top management & Middle management & Lower management & Executive position \\
\hline 2 & 13 & 15 & 72 \\
\hline
\end{tabular}

Source: The research from the doctoral dissertation "Management of the factors of the performance of strategic changes in the organization"

The results show that most respondents were generally satisfied with the quality of information received (47.1\%). The respondents were generally satisfied with their relationship to information $(53.9 \%)$. The respondents $(52.9 \%)$ were generally satisfied with their ability to process information during the day. The largest numbers of respondents $(47.1 \%)$ were neither satisfied nor dissatisfied with the quality of information they receive through television or radio. In addition, the largest numbers of respondents $(48 \%)$ were neither satisfied nor dissatisfied with the quality of information they receive through daily newspapers. The largest numbers of respondents $(65.7 \%)$ were generally satisfied with the quality of information when they needed to make a business decision, and they were also generally satisfied with the quality of information related to their work $(55.9 \%)$.

Characteristics of the respondents included in the random sample (RIRS): The 
structure of respondents included in the random sample was even by gender. Specifically, within the sample, $150(47.6 \%)$ were male and $165(52.4 \%)$ female.

In the observed sample, $93(29.5 \%)$ of respondents were at the age of up to 25 years, $84(26.7 \%)$ were at the age from 26 to $35,72(22.9 \%)$ were at the age from 36 to 45 , and $66(21 \%)$ of the respondents were at the age over 46.

$195(61.8 \%)$ had completed the elementary or secondary school, $36(11.4 \%)$ had completed a college level school or some kind of specialisation, and $84(26.7 \%)$ respondents had university education.

Structure represent: $108(34.3 \%)$ were students, $171(54.3 \%)$ were employed, 18 $(5.7 \%)$ were unemployed, and $18(5.7 \%)$ were retired.

Table 2. showes specifics of the RIRS sample

\begin{tabular}{|c|c|}
\hline \multicolumn{2}{|c|}{ Gender } \\
\hline Male & Female \\
\hline 150 & 165 \\
\hline
\end{tabular}

\begin{tabular}{|c|c|c|c|}
\hline \multicolumn{4}{|c|}{ Age } \\
\hline Up to 25 & 25 to 35 & 36 to 45 & Over 45 \\
\hline 93 & 84 & 72 & 66 \\
\hline
\end{tabular}

\begin{tabular}{|c|c|c|}
\hline \multicolumn{3}{|c|}{ Education } \\
\hline Elementary and secondary & College & Faculty \\
\hline 195 & 36 & 84 \\
\hline
\end{tabular}

\begin{tabular}{|c|c|c|c|}
\hline \multicolumn{4}{|c|}{ Structure } \\
\hline Student & Employed & Unemployed & Retired \\
\hline 108 & 171 & 18 & 18 \\
\hline
\end{tabular}

Source: The research from the doctoral dissertation " Management of the factors of the performance of strategic changes in the organization"

Based on the results, it can be concluded that the highest percentage (45.7\%) of respondents within the covered population were mostly satisfied with the quality of information they receive, and also with their relationship to information (46.7\%). The respondents $(49.5 \%)$ were generally satisfied with their ability to process information received during the day. In the highest percentage (34.3\%), they were neither satisfied nor dissatisfied with the quality of information received through television or radio, meaning they expressed neutral attitude. The highest percentage $(41 \%)$ of respondents also expressed the neutral attitude, that they are neither satisfied nor dissatisfied in relation to the quality of information received through daily newspapers. In the highest percentage $(43.8 \%)$ the respondents were generally satisfied with the quality of information when a decision has to be made. 


\section{Assessment of the information quality when a decision is to be made, respondents in the groups 1-RWES and 2-RIRS with different levels of education}

The survey asked the respondents to assess quality of information when they needed to make a certain decision, with 1 being the highest level of satisfaction and 5 the lowest. Table 3 shows that the respondents in the first group with the completed college or some kind of specialisation are the least satisfied with the quality of information when they need to make a certain decision. Respondents with completed elementary or secondary school in the second group of respondents were the least satisfied with quality of information when they needed to make a business decision (the highest values are mean values).

Table 3: Assessment of quality of information when a decision is to be made by the two groups of respondents with different levels of education

\begin{tabular}{|c|c|c|c|c|}
\hline $\begin{array}{c}\text { GROUPS OF } \\
\text { RESPONDENTS }\end{array}$ & $\begin{array}{l}\text { LEVEL OF } \\
\text { EDUCATION }\end{array}$ & $\begin{array}{c}\text { Mean } \\
\text { MEAN VALUE OF THE } \\
\text { ASSESSMENTS OF QUALITY OF } \\
\text { INFORMATION WHEN } \\
\text { A DECISION } \\
\text { HAS TO BE } \\
\text { MADE }\end{array}$ & $\begin{array}{l}\text { Std. Deviation } \\
\text { STANDARD } \\
\text { DEVIATION }\end{array}$ & $\mathbf{N}$ \\
\hline \multirow{4}{*}{ 1-RWES } & $\begin{array}{l}\text { Elementary or } \\
\text { secondary school }\end{array}$ & 2.18 & .751 & 11 \\
\hline & $\begin{array}{c}\text { College or } \\
\text { some kind } \\
\text { of specialisation }\end{array}$ & 2.36 & .674 & 11 \\
\hline & $\begin{array}{l}\text { University } \\
\text { education }\end{array}$ & 2.31 & .518 & 80 \\
\hline & Total & 2.30 & .559 & 102 \\
\hline \multirow{4}{*}{ 2-RIRS } & $\begin{array}{l}\text { Elementary or } \\
\text { secondary school }\end{array}$ & 2.66 & .811 & 195 \\
\hline & $\begin{array}{c}\text { College or some kind of } \\
\text { specialisation }\end{array}$ & 2.58 & .874 & 36 \\
\hline & University education & 2.71 & .704 & 84 \\
\hline & Total & 2.67 & .790 & 315 \\
\hline \multirow{4}{*}{ Total } & $\begin{array}{l}\text { Elementary or } \\
\text { secondary school }\end{array}$ & 2.64 & .814 & 206 \\
\hline & $\begin{array}{c}\text { College or } \\
\text { some kind } \\
\text { of specialisation }\end{array}$ & 2.53 & .830 & 47 \\
\hline & $\begin{array}{l}\text { University } \\
\text { education }\end{array}$ & 2.52 & .650 & 164 \\
\hline & Total & 2.58 & .756 & 417 \\
\hline
\end{tabular}

Source: The research from the doctoral dissertation "Management of the factors of the performance of strategic changes in the organization"

Diagram 1. illustrates the ratio of the mean values of assessments by two groups of respondents. It can be seen that the mean values with the respondents in the first group are the highest with respondents with completed college or some kind of specialisation, whereas with the respondents in the second group, they are the highest with respondents with completed university education. It can be seen that the respondents of the second 
group are much less satisfied with the quality of information when they have to make a decision compared to the respondents in the first group.

Diagram 1: Difference in assessments of quality of information when a decision has to be made by the two groups of respondents with different levels of education

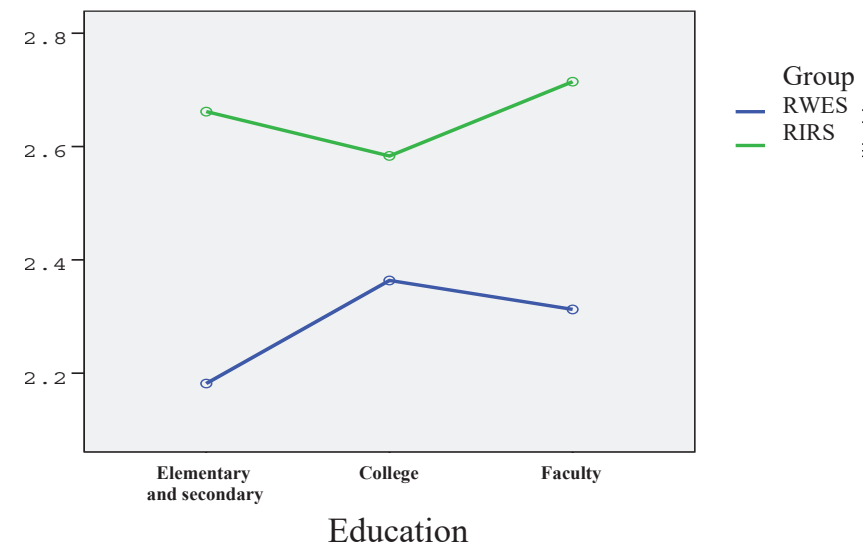

Levene's Test of Equality of Error Variances is $0.000<0.05$, meaning that the variance of the dependent variable is not the same in all groups, so the more stringent significance level $(0.01)$ for the evaluation of the results of the two-factor analysis is taken.

\section{Assessment of information quality when a decision has to be made by the respondents in the groups 1-RWES and 2-RIRS of different age}

The survey asked the respondents to assess quality of information when they need to make a certain decision, with 1 being the highest level of satisfaction and 5 the lowest. It can be seen from Table 4 that the respondents in the first group at the age over 46 assessed quality of the information as the worst when they have to make a decision (the mean values are the highest), whereas in the second group, the respondents from the age of 36 to 45 assessed as the worst quality of information they receive when they have to make a decision. 
Table 4: Assessment of quality of information received by the respondents of the two groups of respondents of different age when a decision has to be made

\begin{tabular}{|c|c|c|c|c|}
\hline $\begin{array}{c}\text { GROUPS OF } \\
\text { RESPONDENTS }\end{array}$ & AGE & $\begin{array}{c}\text { Mean } \\
\text { MEAN VALUE OF THE ASSESSMENTS } \\
\text { OF QUALITY OF INFORMATION } \\
\text { WHEN A DECISION HAS TO BE MADE }\end{array}$ & $\begin{array}{l}\text { Std. Deviation } \\
\text { STANDARD } \\
\text { DEVIATION }\end{array}$ & $\mathbf{N}$ \\
\hline \multirow{5}{*}{ 1-RWES } & Up to 25 & 2.29 & .488 & 7 \\
\hline & 26 to 35 & 2.29 & .457 & 42 \\
\hline & 36 to 45 & 2.27 & .517 & 33 \\
\hline & Over 46 & 2.40 & .821 & 20 \\
\hline & Total & 2.30 & .559 & 102 \\
\hline \multirow{5}{*}{ 2-RIRS } & Up to 25 & 2.39 & .752 & 93 \\
\hline & 26 to 35 & 2.79 & .729 & 84 \\
\hline & 36 to 45 & 2.96 & .740 & 72 \\
\hline & Over 46 & 2.59 & .841 & 66 \\
\hline & Total & 2.67 & .790 & 315 \\
\hline \multirow{5}{*}{ Total } & Up to 25 & 2.38 & .736 & 100 \\
\hline & 26 to 35 & 2.62 & .691 & 126 \\
\hline & 36 to 45 & 2.74 & .747 & 105 \\
\hline & Over 46 & 2.55 & .835 & 86 \\
\hline & Total & 2.58 & .756 & 417 \\
\hline
\end{tabular}

Source: The research from the doctoral dissertation "Management of the factors of the performance of strategic changes in the organization"

Diagram 2. illustrates the ratio of the mean values of assessments by two groups of respondents. It can be seen that the mean values of the first group are the highest with respondents of the age over 46, whereas with the second group, quality of information was assessed as the worst by the respondents aged 36 to 45 . It can also be seen that the respondents of the second group are not satisfied with the quality of information when a decision has to be made.

Diagram 2: Difference in the assessment of quality of information when a decision has to be made by the two groups of different age

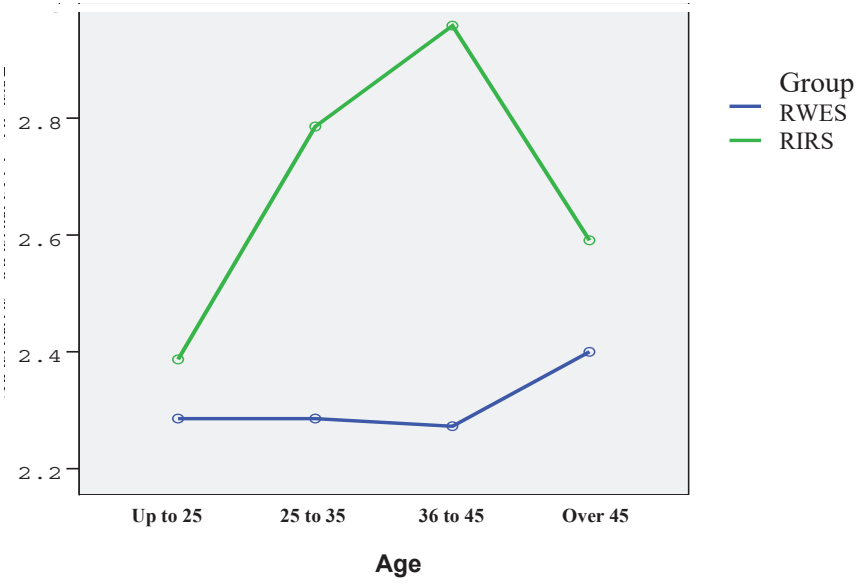


Levene's Test of Equality of Error Variances is $0.000<0.05$, meaning that the variance of the dependent variable is not the same in all groups, so the more stringent significance level (0.01) is taken for the evaluation of the results of the two-factor analysis.

The impact of the interaction between the groups of respondents and the age is given in Table 5. In the column Group of respondents/Age, Sig=0.111, which is more than 0.01 , so it can be concluded that there are no significant differences in the assessments of quality of information by the respondents of different age when a decision has to be made, observed in the two groups of respondents. It means that the impact of the interaction between the groups of respondents and the education is not statistically significant. After the impact of independent variables, we proceeded to analyse separate impacts. Actually, the column Sig for the group of respondents shows the value of 0.000 , and it can be concluded that the separate impacts of the group of respondents influence significantly on the differences in the assessment of quality of information when a decision has to be made. However, Sig for the age is 0.350 which is higher than 0.01 , and it can be concluded that the separate impact of the age does not influence on the differences in the assessment of quality of information. The amount of the influence by the group of respondents is given in the column $\eta^{2}$ (Partial Eta Squared), and it can be seen that it is 0.033 , which is an extremely small impact.

Table 5: Comparative analysis of respondents of different age in the assessment of quality of information they receive when a decision has to be made

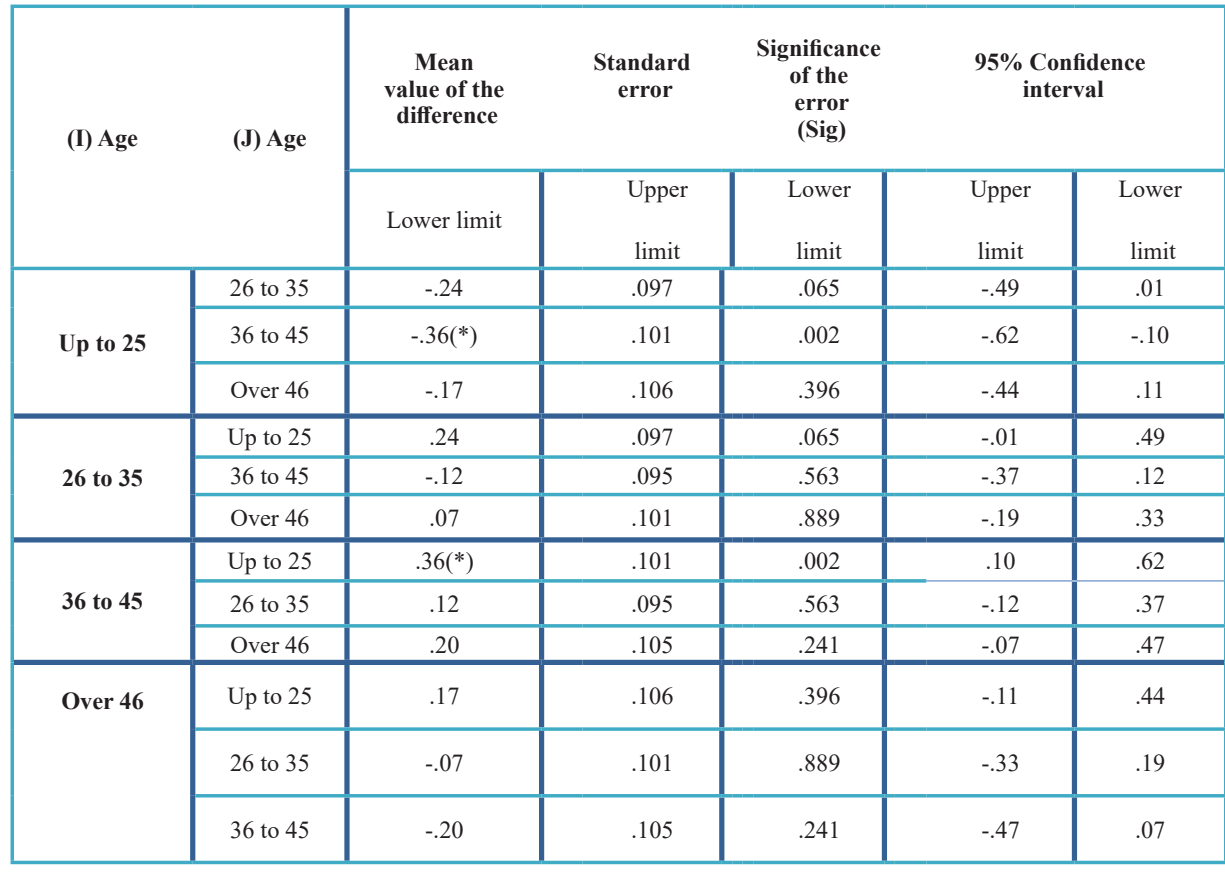

Source: The research from the doctoral dissertation "Management of the factors of the performance of strategic changes in the organization" 


\section{Conclusion}

Managers involved in gathering information in the market and their processing face great challenges every day. It must be an even greater challenge to determine the true direction of moving of the company, despite all the information available to us. False and tactless interpretation of the market signals certainly leads the company in the wrong direction, and we are witnesses that it often happens without any possibility for a second chance. No matter whether the market is of local or international character, it is always an equation with many variables whose solutions are not always unambiguous.

The immediate environment of an organisation can be dynamic or stable. The dynamic environments changes rapidly, the more minimal and slower are the changes, the more stable is the environment. If the decision-makers have to monitor a number of different components in the environment, then such a system is complex. If the number of monitored components is low, such a system is simple. It is thus simply imposed that the environment that is more complex and dynamic is at the same time more uncertain, which makes the job of the managers difficult and requires a lot of information for making appropriate decisions. Reducing uncertainty is achieved only by gathering information and its processing.

It should not be forgotten that people carry everywhere with them their prejudices, religion, cultural assumptions, education, which undoubtedly have a direct impact on the realisation of their projects. Market signals are differently interpreted as different people and cultures differently interpret negotiations, contracts, realisation of projects, and their outcomes. There is no one-sided understanding or a template that certainly gives the ability to always recognise successfully real market signals. Notwithstanding the above, this does not relieve companies from their obligations to monitor the market and market signals, and to make decisions about the company's future based on them.

Based on the results, it can be concluded that, although the respondents were generally satisfied with the quality of information they receive when they need to make a business decision, they have nevertheless expressed a neutral attitude towards television, radio and daily newspapers as a source of information (in most cases, they are not satisfied). Based on this, it can be concluded that business people are increasingly turning to the Internet and getting information through electronic media. Actually, the Internet provides a lot of information in a short period of time and can provide information of the print media and television at one place, whereby the reader is available to filter out what is most important for them.

All this can be sublimated into the famous world chess champion Robert Bobby Fischer's sentence when he was asked how many moves he could see ahead during a game of chess. The answer was: the only one, the best one!

\section{Reference}

Beshears J., \& Gino F. (2015). Leaders as Decision Architects, Harvard Business Review, May

Blenko M., Mankins M., \& Rogers P. (2010). The Decision-Driven Organization. Harvard Business Review, June, 
Cunningham, A.L. (2001). How to Think Like Benjamin Graham and Invest Like Warren Buffett: McGraw-Hill

Friedman L. T. (1999). The Lexus and the Olive Tree; Farrar, Straus and Giroux

Glevick, J. (2012). The Information - A History, a Theory, a Flood:Kindle edition.

Gross M. B. (1964). The managing of organisations: The administrative struggle New York: Free Press of Glencoe.

Jovanović, Z. ( 2015). Management and changes in business environment, Ekonovika, Vol. 61, april-june 2015, № 2 pp. 143-151

Kahneman D., Lovallo D., \&Sibony O. (2011). Before You Make That Big Decision ...., Harvard Business Review, Big Idea, Jun, pp. 51- 60

Lippmann W. (1922). Public Opinion: Harcourt, Brace

McLuhan M. (1962). The Gutenberg Galaxy: The Making of Typographic Man Estate of Carinne McLuhan (2011) and Understanding Media (1964). McGraw Hill

Micić, R. (2015). Leadership role in certain phases of knowledge management processes, Ekonomika Vol. 61, October - December 2015, № 4, pp. 47-56

Milisavljević M. (2001). Marketing: Savremena administracija: Beograd.

Moss, R.W. (2004). Strauss's handbook of business information: a guide for librarians, students, and researchers: Westport, CT: Greenwood Publishing Group, Inc.

Pfiffer, J ( 2009 ) Shareholder First? Not So Fast ... Harvard Business Review, JulyAugust

Porter, M.E. (1980). Competitive Strategy, Free Press, New York

Porter, M.E. (1996). What is Strategy?, Harvard Business Review, November December,

Rogers P., \& Blenko M.(2006), Who Has the D ?, Harvard Business Review, Decision Making, January

Stamatović, M., Vukajlović, Đ., \& Cvetanović, S., (2012): Ocena poslovanja domaćih preduzeća u uslovima rastuće konkurencije i povećanih zahteva tržišta, Megatrend revija, V1.9, No 4, 69-87

Stamenković, S. (2011). Medijska pismenost kao neophodan uslov razumevanja novih medija, Centar za obrazovanje razvoja dece, Niš

Toffler A.(1970), Future Shock, Bantam Books

Wang, R., \& Strong, D. (1996). "Beyond Accuracy: What Data Quality Means to Data Consumers". Journal of Management Information Systems, Vol. 12, No. 4, pp. $5-33$ 